\title{
Impact of Chinese, Korean and Japanese Innovation Spillover on Labour Productivity in South African Manufacturing
}

\author{
Brian Tavonga Mazorodze, Devi Datt Tewari \\ University of Zululand, South Africa \\ brianmazorodze@gmail.com, TewariD@unizulu.ac.za
}

\begin{abstract}
Open economy endogenous growth theories consider physical intermediate imports as a channel through which innovation spreads across international boundaries. We build from this literature and contribute by considering trade in services as the channel through which innovation from China, Korea and Japan influences labour productivity in South Africa's manufacturing sector between 1995Q1 - 2017Q4. Unlike previous studies, we also compute a composite innovation index using the principal component analysis. Results from the autoregressive distributed lag model are supportive of open economy endogenous growth theories for Japan and Korea. However, for China, the effect is significantly negative adding further concerns over its predatory presence in South Africa.
\end{abstract}

Keywords: Innovation spill over, labor productivity, manufacturing, South Africa

\section{Introduction}

The objective of this paper is to estimate the impact of Chinese, Korean and Japanese innovation spill over on labour productivity growth in South Africa's manufacturing sector using recent data. Open economy endogenous growth theories by Aghion and Howitt (1990), Grossman and Helpman (1991) \& Coe and Helpman (1995) and provide the standard theoretical foundation upon which empirical literature on innovation spillover is grounded. These models predict that technology transcends international boundaries through trade in intermediate imports. Consequently, the benefits of innovation created in technology frontier economies can be enjoyed by their technology lagging counterparts. While the literature on this theoretical discourse is well established, a closer look to the existing evidence reveals a number of gaps and shortcomings. First, few studies have considered trade in services as the transmission mechanism. Francois (1990), Mun and Nadiri (2002) and Guerrieri et al. (2005) have shown that services are essential in the role in explaining productivity growth through the linkage and coordination of technology transfers. Empirically, trade in services has gained more prominence in recent decades than trade in physical goods (Balchin et al., 2016). Despite the negligible role given to services as a determinant of long-run productivity growth in traditional growth models, there is little debate that trade in services has become fundamental in transferring skills, knowledge and technology across countries through, for example, service contracts where companies offer technical services abroad. Second, a substantial literature on technology spill over (Apergis et al., 2008, Behera et al., 2012, Nishioka and Ripoll, 2013, Medda and Piga, 2014, Pradeep et al., 2017 and Bloom et al., 2016) has commonly peroxide innovation by research and development (R\&D) stock which is essentially an input in the innovation creation process. According to OECD (2010) however, econometric work needs to divert away from inputs of innovation alone and consider outputs of innovation.

Motivated by this recommendation, we propose and construct, using the principal component analysis (PCA), a novel composite innovation index that comprises both innovation inputs (R\&D stock and human capital in R\&D) and outputs (patent and trademark applications). An autoregressive distributed lag model (ARDL) due to Pesaran and Smith (1998) and Pesaran et al. (2001) is estimated through the bounds testing procedure. This procedure utilizes lags which makes it capable of adequately capturing the underlying data generating process. For robustness purposes, we employ alternative co integrating estimators that adequately remedy the endogeneity problem inherent in the innovation-productivity relation. These include the dynamic ordinary least squares estimation approach (DOLS), the fully modified ordinary least squares method (FMOLS) and the canonical cointegrating regression (CCR) approach. South Africa enjoys strong trade and diplomatic ties with China, Japan and Korea. According to South Africa's Industrial Development Cooperation (IDC) (2009), the majority of South Africa's imports from Asia originate from China, Japan, Korea and Saudi Arabia with a combined $53.5 \%$ share of total imports from the Asian region. In theory, one would expect technology to flow from technology frontier economies to technology lagging ones. Japan, Korea and China have higher per capita incomes relative to South Africa which makes it reasonable to consider the former 
three as technology leading economies. Also, Japan and Korea are service driven economies hence we expect them to transmit innovative and high-quality services to innovation lagging economies like South Africa.

\section{Literature Review}

In theory, trade enhances innovation by facilitating industrial learning through the interchange of technical information across countries. It is essentially through this information exchange process that an innovation lagging economy can simply adopt a superior technology and advanced production ideas that have already been invented in technology frontier countries (Apergis et al., 2008). This phenomenon is commonly referred to as "the advantage of backwardness" in the sense that it prevents the duplication of research efforts. Physical intermediate goods traded globally constitute an important channel for innovation diffusion and transmission in models of endogenous growth developed by Romer (1989) and their extended open economy versions of Grossman and Helpman (1991) and Aghion and Howitt (1990). According to these theoretical models, the use of domestic and foreign-sourced intermediate and capital goods is fundamental in raising and sustaining productivity growth through superior technologies. Empirically, the idea that intermediate imports embody advanced technology and that their use enhances manufacturing productivity growth in the importing country was proposed by Schmookler (1966) and subsequently examined by Terleckyj (1974), Griliches and Lichtenberg (1984), Coe and Helpman (1995) and Keller (2002). Recent literature relies on firm, industry and sectoral level data to analyse the connection and relevant mechanisms linking imports and productivity. Influential firm-level studies such as Melitz (2003), Pradeep et al. (2017) and Medda and Piga (2014) confirm the presence of technology spillover on productivity. Our study is closely related to industry and sectoral level literature which includes Badinger and Egger (2016), Mehta (2013), Nishioka and Ripoll (2012), Raouf Abdel Fattah (2015), Apergis et al. (2008) and Behera et al. (2012).

These studies generally exploit data on manufacturing industries over time and use panel data techniques to explain the empirical link between technological spill over and productivity. The chain of evidence is mixed across most of these studies. For example, Behera et al. (2012) confirm that technology spillover is significant drivers of productivity. On the contrary, Mehta (2013) and Elu and Price (2010) do not find technological spill over to be a significant driver of productivity growth. The latter particularly conclude that international trade between the African region and China is not one which is characterised by technology transfer which is parallel to the prediction raised by Grossman and Helpman (1991). Although the source of result contradiction may not be determined a priori with virtual certainty, it is fair to argue that the source of the controversy lies in the use of different estimation approaches by different studies. A particular important shortcoming of earlier studies is that of disregarding issues of non-stationary as noted by Apergis et al. (2008). The problems of ignoring data stationary property are well known; statistical inference in the conventional ordinary least squares method will be spurious. It is against this background that we perform unit root and cointegration tests which would then allow us so to employ an estimation technique that is less susceptible to spurious inferences. There is however a fair amount of studies that conduct tests for both unit root and cointegration and these include Apergis et al. (2008), Lee (2006) and Guellec et al. (2004). These studies generally find productivity and technology spill over to be cointegrated and hence proceed with cointegrating estimation techniques. To our knowledge however, none of these studies adequately addresses the issue of simultaneity. The correction of simultaneity is critical in this kind of literature as trade variables may also react to changes in productivity growth. Some of the studies including Bloom et al. (2016) rely on instruments while firm-level studies such as one by Ahmed et al. (2015) capitalise on the Olley and Pakes (1992) approach to dealing with the endogeneity issue caused by unobserved productivity shocks.

Relying on the commonly applied Cobb-Douglas production function, Ahmed et al. (2015) conclude, in the context of Pakistan that policies that promote trade encourage productivity growth. Their study did not however focus on the channels through which trade can foster productivity growth. Other studies focus on the channels through which innovation spreads across countries apart from imports. Alvarez (2005) for the Chilean manufacturing industry focus on three main channels of technological absorption namely: exports, foreign direct investment and the purchase of foreign technical licenses. The author finds that exports significantly increase technological innovation. For finds innovation spillover from 16 countries on Egypt's domestic productivity through imports, exports, inward FDI and outward FDI. On the contrary, Goldberg et al. (2010) reach the conclusion that innovation is chiefly transferred through increased access to imported 
inputs. This is similarly confirmed by Kasahara and Rodrigue (2008). Different from these studies, we focus on trade in services as the transmission mechanism. We are interested in services of two forms: 1) commercial presence - which is essentially the provision of a service by a service firm of a technologically advanced economy by establishing a commercial presence in another economy.

This presence can take the form of one services company establishing a branch in a foreign country and 2) the movement of skilled personnel which essentially involves the provision of a particular service through temporary residence of a foreign person in another country. This category can also encompass temporary or permanent migration of independent skilled professionals such as auto-mechanics; electricians, tailors and so on in another country. The ultimate objective is to assess the relevance of service imports in transferring innovation across international boundaries and the eventual effect on labour productivity in the importing country. Our analysis is conducted at sectoral level which necessitates the use of a time series approach. One might question the suitability of a sectoral level approach on the basis of data aggregation issues. Related empirical work in this area - trade in services - tends to rely on aggregated data ${ }^{1}$ often of the cross-section in nature. Mattoo et al. (2006) demonstrate for example using a cross-sectional dataset that countries with liberalized financial and telecommunication sectors exhibit high productivity growth rate. Similarly, Eschenbach and Hoekman (2006) report that liberalization combined with the adoption of good practices in the regulation of telecommunications, financial and energy and transport services are relevant determinants of economic performance. We differ from these studies in that we consider trade in services as a mechanism through which innovation in one country affects productivity in the other. Close to this kind of analysis are studies that consider foreign direct investment as a productivity driver in the host country (Duggan et al. 2013, Arnold et al., 2011a, Fernandes and Paunov, 2012 and Arnold et al., 2016). Indeed, FDI is a key mechanism for the international provision of enabling services and the transfer of knowledge and the knowhow as well as a relevant channel through which high-quality; low-cost services can improve TFP of manufacturing producers in the host country. However, our analysis aggregates a broad range of services other than FDI which makes it capable of providing a complete picture of how trade in services influences the productivity of the importing country as an innovation transmission mechanism.

\section{Methodology}

The sampling period is 1995 - 2017 guided by data availability. Despite the issue of data considerations, this period coincidentally represents the era in which trade between South Africa, China, Korea and Japan grew remarkably. In order to increase the sample size, the annual data are converted into quarterly intervals using the quadratic interpolation method. This transformation yields a sample size of 92 observations. The rest of the paper proceeds as follows: Section 2.0 reviews related literature, 3.0 describes the data and specifies empirical models, 4.0 reports and discusses the findings while 5.0 highlights some concluding remark.

Model Specification: To ascertain the impact of innovation embodied in service imports from China, Korea and Japan, we specify a multivariate model of the following form ${ }^{2}$ :

$$
\begin{gathered}
\log L P_{t}=\beta_{0}+\beta_{1} \log S_{t}+\beta_{2} \log C_{t}+\beta_{3} \log K_{t}+\beta_{4} \log J_{t}+\varepsilon_{t} \\
t=1995 Q 1, \ldots, 2017 Q 4
\end{gathered}
$$

where log denotes logarithm, $\beta_{0}-\beta_{4}$ are unknown parameters to be estimated, $t$ signifies time period, $\varepsilon_{t}$ is the white noise error term, $L P$ is labour productivity defined as real output per worker in manufacturing. By focusing on productivity at sectoral level, we are making an assumption that manufacturing productivity draws from a common pool of technology. Variable $S$ represents South Africa composite innovation index $C K$ and $J$ are composite innovation indices for China, Korea and Japan respectively so that their corresponding slope parameter represent spill over effects. The composite innovation indices are computed using the

\footnotetext{
${ }^{1}$ Also one of the pioneering works by Coe and Helpman (1995) was even more aggregated as it was conducted at country level.

2This model theoretically builds from open economy versions of endogenous growth models by Coe and Helpman (1995). It is similar to that applied in Badinger et al. (2016), Mehta (2013), Nishioka and Ripoll (2013), Apergis et al. (2008) and Behera et al. (2012). The difference is that we focus on innovation transferred via service imports rather than R\&D embodied in physical imports.
} 
principal component analysis (PCA). The PCA is essentially a mathematical procedure that allows us to transform the correlated innovation indicators into an overall index called a principal component. It has two broad objectives namely reducing the dimensionality of a given data set and constructing new variable(s). In our case, we have four indicators of innovation namely R\&D stock, researchers in R\&D, patent and trademark applications and we compute a principal component index for each country. Human capital, just like R\&D expenditure is a key input of innovation creation.

Empirically, there is a widespread consensus that education systems, through postgraduate research for example, significantly contribute to the knowledge bases. By definition, human capital here is quantified by the number of researchers in R\&D. These are essentially professionals employed in the generation of new knowledge, products, production processes or production systems. Postgraduate Ph.D. students engaged in R\&D are also included by measurement. The stock of $R \& D$ is calculated based on the perpetual inventory method (PIM). Using this method, R\&D stock $\left(Z_{t}\right)$ at the beginning of period $\mathrm{t}$ is equal to the beginning stock $\left(Z_{t-1}\right)$ plus expenditure on $\mathrm{R} \& \mathrm{D}$ in the current year $\left(R_{t}\right)$ subtract beginning stock depreciation $\left(\delta Z_{t-1}\right)$ where $\delta$ refers to the rate of yearly depreciation.

$\mathrm{R} \& \mathrm{D}$ stock in the initial year $Z_{0}$ is given by:

$$
Z_{t}=(1-\delta) Z_{t-1}+R_{t}
$$

$$
Z_{0}=R_{1} /(\delta+\mathrm{g})
$$

Here,g denotes the average yearly logarithmic R\&D growth rate from $Z_{0}$ to the current period. Since initial R\&D stock is not directly observed, we have measured it with an assumption that R\&D expenditure and $\delta$ prior the initial period equals the average rates observed after the initial year. We have also assumed a depreciation rate of 15 per cent in line with Feldman and Kogler (2010) and Hall and Rosenberg (2010). Part of the novelty of our index is the inclusion of trademarks which are strongly used by firms when introducing new products mainly as a way of symbolising novelty and promoting the product brand so that the rewards of their innovation effort can be appropriated. With these four indicators, the PCA allows us to establish the weights of each indicator included in the overall index arbitrarily in a way that ensures that the final component (s) explain maximum variance in the data. We name the constructed index for each countryPCI. The next question becomes; how is innovation represented by this proxy transmitted from Korea, Japan and China to South Africa with an ultimate effect on labour productivity in manufacturing? As indicated in literature, several channels have been identified but we focus on weights based on service imports. How do these services link with innovation transfer and productivity growth? Despite being excluded in conventional growth models, trade in services has a strong impact on technology transfer and productivity growth.

Financial services for instance can influence productivity growth by facilitating the process of capital accumulation as well as fostering innovation (Levine, 1997). Telecommunications services that are of high quality and low costs result in sectoral and economy-wide benefits given that communication networks represent a way of transferring and conveying information regarding non-codified knowledge. In other words, telecommunications play an import role in the dissemination and diffusion of innovation and knowledge - including the use of the internet - i.e. the internet of things. A sound and robust network communication can also act as a transmission mechanism of digitised intermediate products. Similarly, efficient transport services can have an influence on the cost of shipment for goods as well as the migration of skilled personnel between countries. Business services that encompass consultancy, engineering and so on reduce transaction costs that are associated with the enforcement of business contracts and they also stand as a mechanism through which business process innovations are transmitted across countries.

Given this importance of services and following Lichtenberg and Pottels berghe de la Potterie (2001), the innovation spill over variable weighted by service imports is measured as:

$$
\begin{aligned}
C_{i t} & =\sum_{j} \frac{S_{-} I M P_{i j t}}{Y_{j t}} P C I_{j t} \\
K_{i t} & =\sum_{j} \frac{S_{-} I M P_{i j t}}{Y_{j t}} P C I_{j t} \\
J_{i t} & =\sum_{j} \frac{S_{-} I M P_{i j t}}{Y_{j t}} P C I_{j t}
\end{aligned}
$$


where $S_{-} I M P$ represents service imports of country $i$ (South Africa in this case) from countryj, where $j=$ China, Japan and Korea, $Y_{j t}$ denotes GDP of the transmitting country and $P C I_{j t}$ refers to the composite innovation index computed by the principal component analysis. Theoretically, open economy endogenous growth models by Grossman and Helpman (1991), Coe and Helpman (1995), Aghion and Howitt (1990) predict a positive effect of technology transfer on productivity of the importing country. Empirically, however, studies have shown that the effect can be negative. Therefore, either sign is expected on innovation spill over parameters. Data are sourced from different sources. Labour productivity in manufacturing is extracted from the South African. Reserve Bank (SARB), researchers in R\&D and R\&D expenditure is from OECD.

Estimation Procedure: The World Development Indicators (WDI), patent and trademark applications are sourced from WDI. With time series, it is important to first check the data generating process so as to avoid making spurious inferences which occur when we estimate a seemingly strong relationship which does not exist. To achieve this, we apply the Breakpoint unit root approach, the Augmented-Dickey-Fuller (ADF), Phillip-Perron (PP) as well as the Kwiatkowski-Phillips-Schmidt-Shin (KPSS) approaches for robustness purposes. Apart from the KPSS, the entire tests have a null hypothesis of a non-stationary process. Having checked the data generating process, we apply the linear ARDL bounds testing procedure proposed by Pesaran and Smith (1998) and Pesaran et al. (2001) which has the main advantage of being applicable even in the presence of I( 0$)$ and $1(1)$ regresses. With the ARDL bounds testing procedure, equation (1) becomes.

$$
\begin{aligned}
\Delta \log L P_{t}=\theta_{0}+ & \theta_{1} \log L P_{t-1}+\theta_{2} \log C_{t-1}+\theta_{3} \log J_{t-1}+\theta_{4} \log K_{t-1}+\theta_{5} \log S_{t-1} \\
& +\sum_{i=1}^{n} \beta_{i} \Delta \log L P_{t-i}+\sum_{i=1}^{n} \varphi_{i} \Delta \log C_{t-i}+\sum_{i=1}^{n} \alpha_{i} \Delta \log J_{t-i}+\sum_{i=1}^{n} w_{i} \Delta \log K_{t-i}+\sum_{i=1}^{n} a_{i} \Delta \log S_{t-i} \\
& +\varepsilon_{t} \quad(2) \quad t=1995 Q 1, \ldots, 2017 Q 4
\end{aligned}
$$

where $\Delta$ denotes the first difference operator. The optimum lag order for each regressor is automatically selected by the Akaike Information Criterion (AIC) which, according to Lütkepohl (2006), performs better than other alternatives. In performing the bounds testing procedure, we first estimate equation (2) by the OLS method and test for joint significance of lagged level variable parameters using an F-test. The corresponding F-statistic in the bounds testing procedure has a distribution which is non-standard and more importantly one which is dependent upon four key factors namely (i) the number of observations (n), i.e. sample size (ii) number of covariates less the lagged dependent variable (i.e. k-1) in the ARDL specification, (iii) the assumption of an intercept and the trend component and (iv) whether none of the variables is I (2). In this study, our sample size (n) is 92 and the number of regresses excluding the lagged dependent variable is 4. With regards to the inclusion of a trend and constant, case three is assumed. Importantly, none of the variables is I (2) as will be shown in the subsequent section. Critical values are tabulated in Pesaran et al. (2001) for the lower and the upper bound. An F-statistic above (below) the upper (lower) bound signals presence (absence) of a long-run association while the test is not conclusive if the F-statistic lies in between the upper and the lower bound.

The $H_{0}$ of no long-run association is given by, $\theta_{1}=\theta_{2}=\theta_{3}=\theta_{4}=\theta_{5}=0$ against the $\mathrm{H}_{\mathrm{A}}: \theta_{1} \neq \theta_{2} \neq \theta_{3} \neq$ $\theta_{4} \neq \theta_{5} \neq 0$. This can be denoted by $F_{P}(\log L P \mid C, K, J, S)$. If co integration is confirmed in the equation that is normalised with labour productivity, then equation (2) can bare-specified into an error-correction-model (ECM) of the following form:

$$
\Delta \log L P_{t}=c+\sum_{i=1}^{n} \beta_{i} \Delta \log L P_{t-i}+\sum_{i=1}^{n} \varphi_{i} \Delta \log C_{t-i}+\sum_{i=1}^{n} \alpha_{i} \Delta \log K_{t-i}+\sum_{i=1}^{n} w_{i} \Delta \log J_{t-i}+\sum_{i=1}^{n} \eta_{i P} \Delta \log S_{t-i}
$$

Adding to the variables already defined; $\mathrm{ECT}_{\mathrm{t}-1}$ represents a year lagged $\mathrm{ECT}$ term that reconciles long-run information with short-run dynamics. For robustness purposes, ARDL results are compared with those from alternative estimators - the DOLS, the FMOLS and the CCR techniques. 
Table 1: Japan Eigen Values and Factor Loadings

\begin{tabular}{lllll}
\hline & F1 & F2 & F3 & F4 \\
\hline Eigen value & 2,248 & 0,903 & 0,708 & 0,140 \\
Variability (\%) & 56,211 & 22,585 & 17,700 & 3,504 \\
Cumulative (\%) & 56,211 & 78,796 & 96,496 & 100,000 \\
Japan Factor loadings & F1 & F2 & F3 & F4 \\
R\&D stock & 0,945 & 0,128 & 0,104 & 0,282 \\
Patents & 0,684 & 0,691 & 0,148 & 0,181 \\
R\&D Researchers & 0,724 & 0,414 & 0,528 & 0,160 \\
Trademarks & 0,603 & 0,488 & 0,630 & 0,045 \\
Kaiser-Meyer-Olkin & 0,788 & & & \\
\hline
\end{tabular}

Table 2: Korea Eigen Values and Factor Loadings

\begin{tabular}{lllll}
\hline & F1 & F2 & F3 & F4 \\
\hline Eigen value & 3,867 & 0,086 & 0,044 & 0,003 \\
Variability (\%) & 96,678 & 2,145 & 1,099 & 0,078 \\
Cumulative (\%) & 96,678 & 98,823 & 99,922 & 100,000 \\
Japan Factor loadings & F1 & F2 & F3 & F4 \\
R\&D stock & 0,987 & $-0,127$ & $-0,092$ & $-0,034$ \\
Patents & 0,993 & $-0,108$ & $-0,026$ & 0,043 \\
R\&D Researchers & 0,984 & $-0,002$ & 0,177 & $-0,011$ \\
Trademarks & 0,969 & 0,241 & $-0,059$ & 0,001 \\
Kaiser-Meyer-Olkin & 0,752 & & & \\
& & & & \\
Table 3: China Eigen Values and Factor Loadings & & & & \\
\hline & F1 & F2 & F3 & F4 \\
\hline Eigen value & 3,686 & 0,270 & 0,036 & 0,009 \\
Variability (\%) & 92,139 & 6,745 & 0,892 & 0,224 \\
Cumulative \% & 92,139 & 98,884 & 99,776 & 100,000 \\
& F1 & F2 & F3 & F4 \\
R\&D stock & 0,993 & $-0,054$ & $-0,076$ & 0,071 \\
Patents & 0,896 & 0,442 & 0,043 & $-0,008$ \\
R\&D Researchers & 0,960 & $-0,245$ & 0,137 & $-0,002$ \\
Trademarks & 0,988 & $-0,107$ & $-0,096$ & $-0,063$ \\
Kaiser-Meyer-Olkin & 0,794 & & & \\
\hline
\end{tabular}

To verify the applicability of the ARDL bounds testing procedure, we evaluated the integration properties of the data using four tests for stationary. Three out of four tests in table 4 confirm that the variables are stationary in levels and that none of them is I (2) which gives us the green light to apply the ARDL technique. The calculated F-statistics are presented in Table 5 and the outcome points to the presence of one cointegrating vector in which $\log L P$ is the dependent variable. This is the equation in which the calculated Fstatistic is above the 5\% critical upper bound. According to Pesaran et al. (2001) a long-run relationship exists if the calculated F-statistic is above the 5\% upper bound critical value. For equations normalised with other regresses, the test either does not find a long-run relationship or is rather inconclusive. 
Table 4: Unit Root Tests

\begin{tabular}{lrlllll}
\hline Variable & & Break-Point & ADF & PP & KPSS & \begin{tabular}{l} 
Order $\begin{array}{c}\text { of } \\
\text { integration }\end{array}$ \\
\hline LNLP
\end{tabular} \\
& Levels & 2.423 & 1.253 & $2.840^{*}$ & $1.219^{* * *}$ & $\mathrm{I}(1)$ \\
LNS & $\Delta$ & $6.852^{* * *}$ & $2.940^{* *}$ & ----- & 0.438 & \\
& Levels & 3.686 & 1.641 & 0.846 & $0.998^{* * *}$ & $\mathrm{I}(1)$ \\
LNC & $\Delta$ & $4.237^{*}$ & TI5.926*** & $3.357^{* *}$ & 0.082 & \\
& Levels & 1.729 & 0.782 & $3.087^{* *}$ & $1.177^{* * *}$ & $\mathrm{I}(1)$ \\
LNJ & $\Delta$ & $4.976^{* * *}$ & $3.956^{* * *}$ & ---- & 0.439 & \\
& Levels & 1.255 & TI 1.896 & 0.708 & $0.715^{* *}$ & $\mathrm{I}(1)$ \\
LNK & $\Delta$ & $17.255^{* * *}$ & $2.361^{* *}$ & $3.136^{* * *}$ & 0.346 & \\
& Levels & 1.389 & 1.787 & $15.741^{* * *}$ & $1.142^{* * *}$ & $\mathrm{I}(1)$ \\
\hline
\end{tabular}

Note: $*, * *, * * *$ denote $\mathrm{p}<0.1, \mathrm{p}<0.05 \& \mathrm{p}<0.01$ respectively. ${ }^{\mathrm{TI}}=$ specification with trend \& intercept. Figures in tables are test statistics for the Break-Point, ADF \& PP tests. For the KPSS, the figures represent the LMstatistic. ADF = Augmented Dickey-Fuller, PP=Phillips-Perron, KSS=Kwiatkowski-Phillips-Schmidt-Shin

Table 5: Bounds F-tests for Co Integration

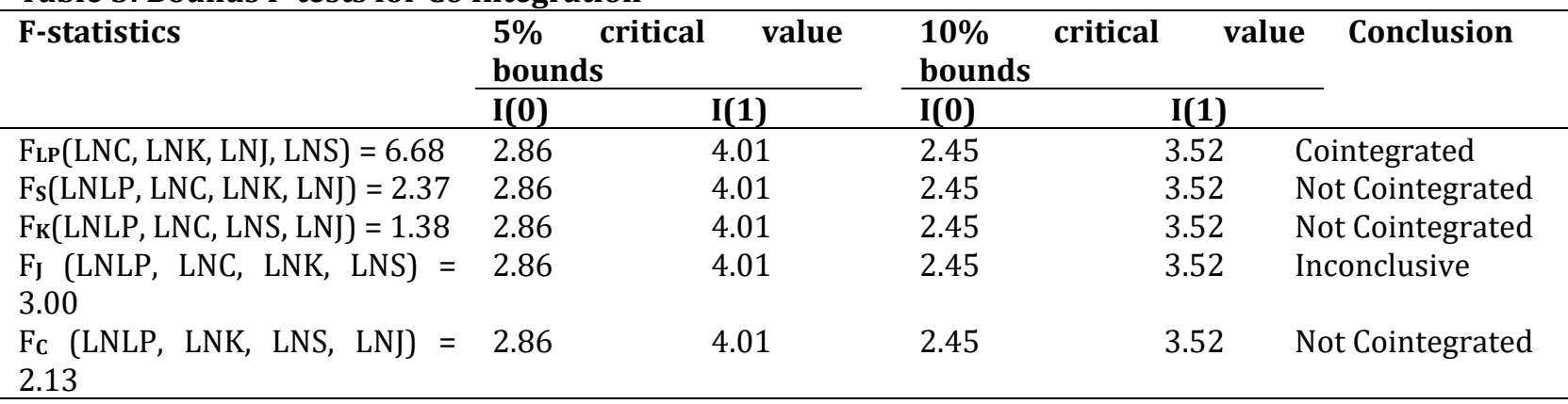

Note: Critical values are obtained from Pesaran et al. (2001), k=4, Case III is assumed i.e. unrestricted intercept and no trend.

\section{Results and Discussion}

Principal components results are attached in the appendix for brevity sake. In table 1out of four factors; the first two components explain about 79\% variation of the overall index for Japan and $98.8 \%$ variation for Korea and China. In all cases, the Kaiser-Meyer-Olkin is above the 0.6 threshold which provides justification for using the principal component analysis. Interesting is that in all cases i.e. for Japan, China and Korea, all the four indicators load highly in the first factor. It is also the first factor - R\&D stock - that is retained as its Eigenvalues are more than 1 in all cases, 2.3 for Japan, 3.9 for Korea and 3.7 for China. Our main specification that is normalized with labour productivity $(L P)$ is based on an ARDL $(10,5,9,10,5)$ automatically selected by the AIC as shown in figure 1. For brevity, short-run results are not reported. We therefore report only long-run parameters with Newey-West standard errors in table 6. Newey-West standard errors are used due to the prevalence of autocorrelation and heteroscedasticity (see table 7). Three results are noteworthy. First, innovation spill over transmitted through service imports from China enters with a significantly negative effect on labour productivity which supports Asongu et al. (2011), Renard (2011) and Diaw and Lessoua (2013).

A $10 \%$ increase in innovation from China reduces South Africa's labour productivity in manufacturing by $0.09 \%$ on impact holding constant other regresses. This is not a surprising result in literature. According to Koumou et al. (2016), it is often claimed that Chinese investments in Africa bring more harm than good to the economy, and that Chinese are predators of the African raw materials. Second, innovation from Korea and Japan enter with the expected positive and significant effects predicted by Grossman and Helpman (1991) open economy endogenous growth theory. According to the results, a $10 \%$ increase in innovation spill over from Korea $(\operatorname{lnK})$ and Japan (lnJ) raises South Africa's labour productivity in manufacturing by $0.24 \%$ and 
$0.13 \%$ on impact respectively holding domestic innovation $(\ln S)$ and innovation from China (lnC) constant. This is empirically consistent with studies such as Nishioka and Ripoll (2013) and Acharya and Keller (2009) which all confirmed a positive effect of spillover effects on manufacturing productivity of the importing country. Third, domestic innovation has a larger effect on labour productivity as compared to innovation from Japan and Korea. A 10\% increase in domestic innovation is estimated to raise labour productivity by $2.1 \%$ holding constant foreign innovation spill over.

This is in agreement with results reported in Acharya and Keller (2009), where domestic R\&D stock is found to have a relatively greater impact on manufacturing productivity of the importing country. According to Piermartini and Rubínová (2014), this may be the case because foreign knowledge is less accessible relative to domestic knowledge owing to barriers related to such things as language and cultural differences. For robustness check, the long-run parameters were estimated by the DOLS, FMOLS and CCR techniques with Newey-West standard errors. The DOLS is estimated with 3 leads and 3 lags selected by the AIC. Coefficients of leads and lags are not reported for brevity sake. Results are reported in table 6 and they are confirmatory in that; i) Chinese innovation spillover have a negative effect on labour productivity, ii) Korean and Japanese innovation spillover have a positive effect and that iii) domestic innovation has a relatively larger effect on labour productivity. The evidence suggests however that the ARDL appears to over-estimate (upwards bias).

Table 6: Long-Run Estimates: Dependent Variable: $\log$ LP

\begin{tabular}{lllll}
\multicolumn{1}{c}{ Regresses } & ARDL & DOLS & FMOLS & CCR \\
\hline \multirow{2}{*}{$\log$ South Africa $(\log \mathrm{S})$} & $0.210^{* * *}$ & $0.125^{* *}$ & $0.124^{* *}$ & $0.124^{* *}$ \\
& $(0.042)$ & $(0.062)$ & $(0.055)$ & $(0.055)$ \\
$\log$ Korea $(\log \mathrm{K})$ & $0.024^{* * *}$ & $0.059^{*}$ & $0.053^{* * *}$ & $0.053^{* * *}$ \\
& $(0.005)$ & $(0.009)$ & $(0.007)$ & $(0.007)$ \\
$\log$ Japan $(\log \mathrm{J})$ & $0.013^{* * *}$ & $0.010^{* *}$ & $0.011^{* * *}$ & $0.011^{* * *}$ \\
& $(0.004)$ & $(0.004)$ & $(0.003)$ & $(0.003)$ \\
$\log$ China $(\log \mathrm{C})$ & $-0.010^{* * *}$ & $-0.042^{* * *}$ & $-0.036^{* * *}$ & $-0.036^{* * *}$ \\
& $(0.003)$ & $(0.007)$ & $(0.006)$ & $(0.006)$ \\
$\mathrm{C}$ & 4.647 & 4.999 & 4.999 & 4.999 \\
& $(0.167)$ & $(0.185)$ & $(0.227)$ & $(0.227)$ \\
Adj. R-squared & 0.903 & 0.956 & 0.961 & 0.953 \\
Hansen Prob. & & $>0.2$ & $>0.2$ & $>0.2$ \\
No of Obs. & 82 & 85 & 91 & 91 \\
\hline
\end{tabular}

Note: $* * *, * * *$ denote $\mathrm{p}<0.1, \mathrm{p}<0.05 \& \mathrm{p}<0.01$ respectively. Figures in parenthesis are Newey-West Standard errors the DOLS is estimated with 3 leads and 3 lags.

The effect of domestic innovation owing to its insufficient ability to adequately address the simultaneity problem, the adjusted R-squared is over $90 \%$ across all the variants, which makes the estimated model capable of explaining variations in labour productivity. All specifications were subjected to a battery of diagnostic tests. These include residual normality using the Jarque-Bera test, autocorrelation using the Breusch-Godfrey Serial Correlation LM test, heteroscedasticity using the Breusch-Pagan-Godfrey test, model specification using the Ramsey RESET test and parameter stability using the CUSUM test for parameter stability. Results suggested that the models passed the parameter stability, model specification and residual normality test and failed heteroscedasticity and autocorrelation. As a corrective measure, Newey-West standard errors were used. The results are shown in table 7. The Hansen probability value in table 6 tests the null of no cointegration post estimation of the DOLS, FMOLS and the CCR. In all cases, the probability value exceeds $20 \%$ which indicates insufficient statistical evidence to reject the null. This outcome points to a cointegrating relationship substantiating the bounds testing results reported in table 5 . The error correction term of the ARDL attached in appendix is 0.12 indicating that $12 \%$ of the disequilibrium is corrected each quarter. It therefore takes about 2 years for the model to revert back to the equilibrium position in the event of a short-run discrepancy. 
Figure 1: Model Selection Criterion

Akaike Information Criteria (top 20 models)

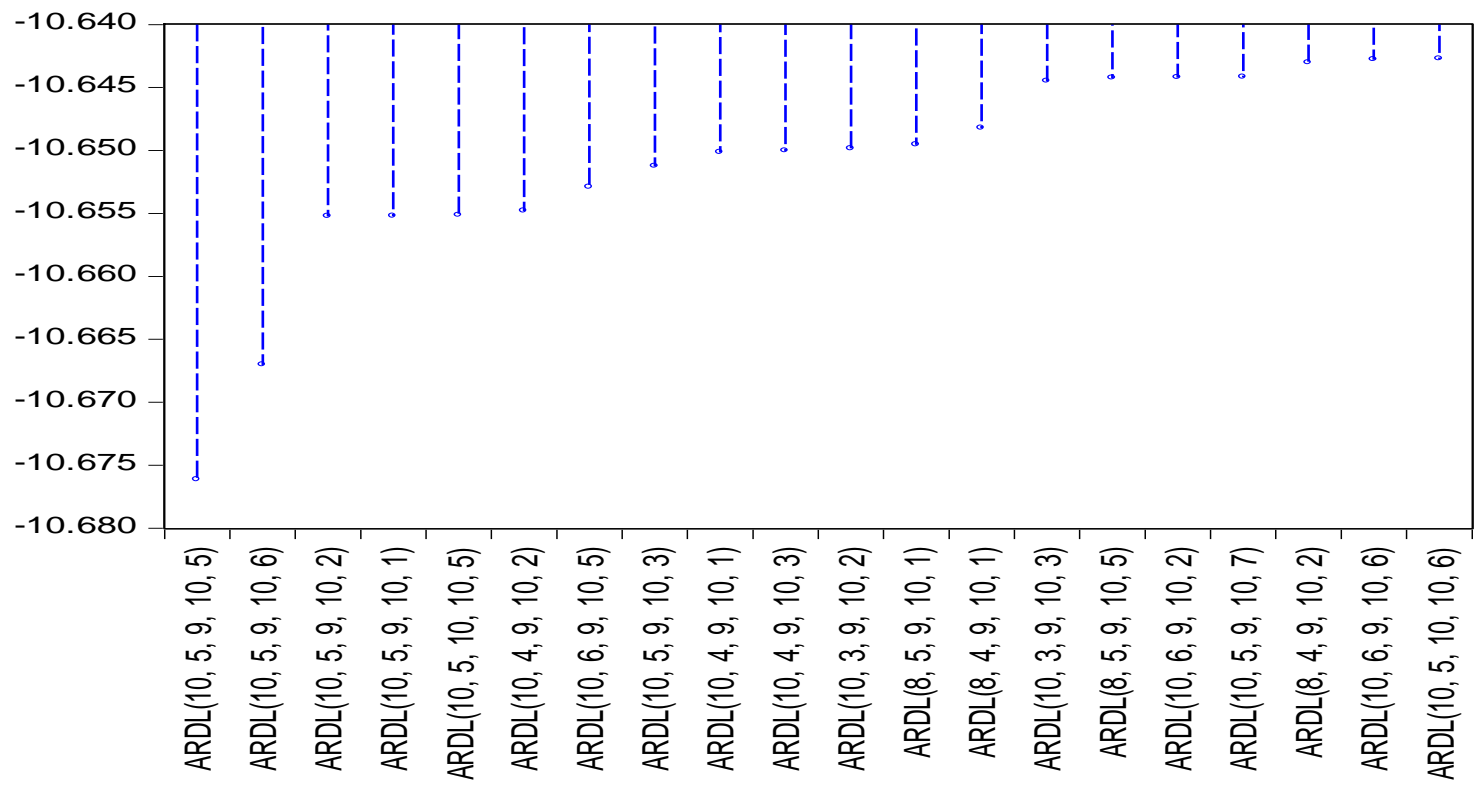

Figure 2: CUSUM Test for Parameter Stability

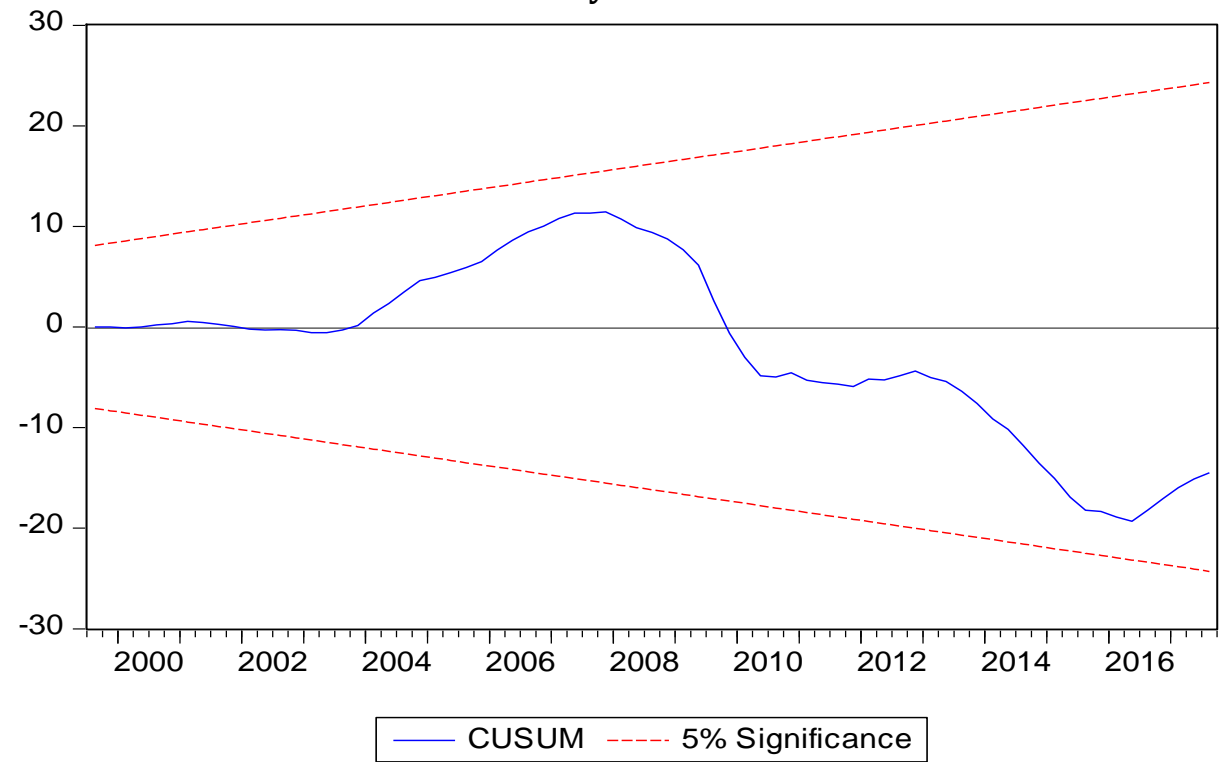

Table 7: Diagnostic Tests

\begin{tabular}{lll}
\hline Test & F-statistic & Probability Value \\
\hline Breusch-Godfrey Serial LM test & F-statistic $=41.944$ & Pro b F $(2,74)=0.0000$ \\
Breusch-Pagan-Godfrey test & F-statistic $=2.010$ & Pro b F $(12,76)=0.0345$ \\
Ramsey RESET test & F-statistic $=0.3089$ & Pro b $=0.5800$ \\
\hline
\end{tabular}


Figure 3: Jarque-Bera Test

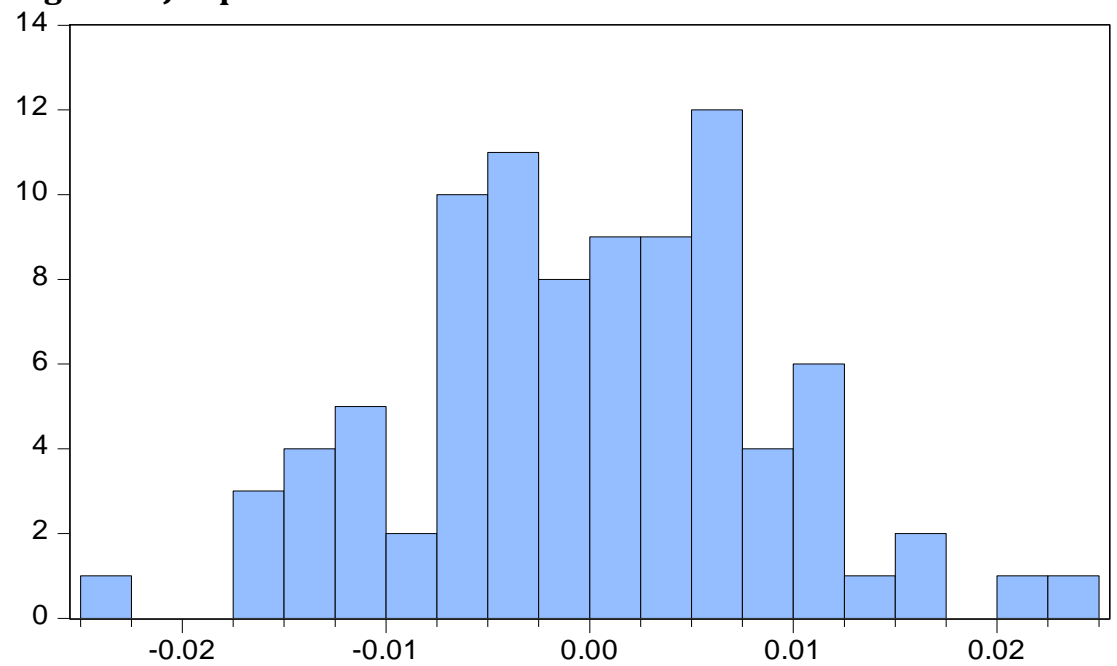

Series: Residuals

Sample 1995Q3 2017Q3

Observations 89

Mean

$-1.01 \mathrm{e}-17$

Median

0.000233

Maximum $\quad 0.024915$

Minimum $\quad-0.024593$

Std. Dev. $\quad 0.008945$

Skewness $\quad 0.046467$

Kurtosis $\quad 3.181007$

Jarque-Bera $\quad 0.153526$

Probability $\quad 0.926109$

How robust are these results? First we decompose the total sample into two sets 1995Q1 - 2008Q4 and 2009Q1 - 2017Q4. This decomposition allows us to establish whether or not the relationship between foreign innovation spillover has changed over time particularly pre and post the 2009 global financial crisis. The results in table 8variant (1) represent the 1995Q1 - 2008Q4 subsample and they are based on an ARDL 11,4 , $4,4,3)$ automatically selected by the AIC with Newey-West standard errors. Because the sample has 56 quarterly observations after adjusting for degrees of freedom, we rely on critical values re-formulated Narayan (2004). These critical values are suitable for small sample sizes ranging from 30 to 80 observations. The computed F-statistic is 18.99 which is above the $3.8135 \%$ upper critical bound given $\mathrm{n}=56$, $\mathrm{k}=4$ with an intercept and no trend. This provided the green light to estimate the long-run estimates. Similarly, for variant (2), the F statistic is 4.693 which is above the $4.0625 \%$ upper critical bound given $n=36$ and $k=4$. As shown in table 8, the sample decomposition does not bring significant alterations to the main results i.e. Chinese innovation correlate negatively with productivity, Korea and Japanese innovation spill over correlate positively but domestic innovation stock has a larger effect. Lastly we change our interpolation method from quadratic to linear interpolation when converting our initial annual data to quarterly data. The results in table 9are based on an ARDL $(2,0,2,2,2)$ again automatically selected by the AIC. Following the same stages, i.e. the bounds testing procedure for the entire sample, the results in table 8 corroborate the central result that Chinese innovation is harmful to labour productivity in South Africa's manufacturing sector, Japanese and Korean innovation spillover have the opposite effect but domestic innovation has a larger effect.

Table 8: ARDL Long-Run Estimates - Sub Samples: Dependent Variable: Log LP

\begin{tabular}{lll}
\hline Regresses & Variant (1) & Variant (2) \\
& $\mathbf{1 9 9 5 Q 1 - 2 0 0 8 Q 4}$ & $\mathbf{2 0 0 9 Q 1}-2$ \\
\hline \multirow{2}{*}{$\log$ South Africa $(\log \mathrm{S})$} & $0.288^{* *}$ & $0.255^{* * *}$ \\
& $(0.107)$ & $(0.054)$ \\
$\log$ Korea $(\log \mathrm{K})$ & $0.091^{* * *}$ & $0.043^{* * *}$ \\
& $(0.013)$ & $(0.009)$ \\
$\log$ Japan $(\log \mathrm{J})$ & $0.014^{* * *}$ & $0.004^{* *}$ \\
& $(0.002)$ & $0.002)$ \\
$\log$ China $(\log \mathrm{C})$ & $-0.103^{* * *}$ & $-0.050^{* * *}$ \\
& $(0.029)$ & $(0.007)$ \\
$\mathrm{C}$ & 4.309 & 6.610 \\
& $(0.453)$ & $(0.224)$ \\
Adj. sample size & 54 & 33
\end{tabular}

Note: ${ }^{*}, * * * *$ denote $\mathrm{p}<0.1, \mathrm{p}<0.05 \& \mathrm{p}<0.01$ respectively. Figures in parenthesis are Newry West standard errors 
Table 9: ARDL Estimates - Linearly Interpolated Data: Dependent variable: log LP

\begin{tabular}{lllll}
\hline Regresses & Coefficient & Std. Error & t-Statistic & Prob. \\
\hline $\log$ South Africa(log S) & & & & \\
$\log$ Korea $(\log K)$ & 0.295 & 0.095 & 3.09 & 0.0028 \\
$\log$ Japan $(\log J)$ & 0.035 & 0.012 & 2.92 & 0.0045 \\
$\log$ China $(\log$ C) & 0.008 & 0.001 & 8.00 & 0.0000 \\
C & -0.021 & 0.009 & -2.24 & 0.0279 \\
& 4.289 & 0.396 & 10.823 & 0.0000 \\
\hline
\end{tabular}

\section{Concluding Remarks}

In this paper, we have constructed a composite innovation index that comprises R\&D stock, R\&D researchers, patents and trademarks using the principal component analysis. Different from previous studies, service imports are used as the transmission mechanism. Three results are noteworthy. First, service imports have a fundamental role in transferring innovation across international boundaries and this is true for Japan and Korea in which domestic labour productivity is raised within the $0.01 \%-0.06 \%$ range. Second, although innovation from Korea and Japan correlates significantly with labour productivity, it is domestic innovation that has a relatively larger effect on productivity. Based on the evidence, a number of concluding remarks can be made. First, the results imply that domestic policy that affects trade in services with Korea and Japan such as restrictive rules and regulations can deny South Africa an opportunity to raise labour productivity through absorption of foreign innovation that comes along with their services. The second implication of our results is that labour productivity is more sensitive to domestic innovation which means that foreign innovation that might be transferred through service imports has to be treated as a complement rather than a substitute for domestic innovation efforts.

\section{References}

Acharya, R. C. \& Keller, W. (2009). Technology Transfer Through Imports. Canadian Journal of Economics/Revue canadienne d'économique, 42(4), 1411-1448.

Ahmed, G., Arshad Khan, M. \& Afzal, M. (2015). Trade Liberalization and Industrial Productivity: Evidence from Pakistan.

Alvarez, R. \& Lopez, R. A. (2005). Exporting and Performance: Evidence from Chilean Plants. Canadian Journal of Economics/Revue canadienne d'économique, 38(4), 1384-1400.

Arnold, J., Nicoletti, G. \& Scarpetta, S. (2011). Regulation, Resource Reallocation and Productivity Growth. Nordic Economic Policy Review, 2, 61-94.

Arnold, J. M., Javorcik, B., Lipscomb, M. \& Mattoo, A. (2016). Services Reform and Manufacturing Performance: Evidence from India. The Economic Journal, 126(590), 1-39.

Apergis, N., Economidou, C. \& Filippidis, I. (2008). Innovation, Technology Transfer and Labor Productivity Linkages: Evidence from a Panel of Manufacturing Industries. Review of World Economics, 144(3), 491-508.

Aghion, P. \& Howitt, P. (1990). A Model of Growth Through Creative Destruction (No. w3223). National Bureau of Economic Research.

Asongu, S. A. \& Aminkeng, G. A. (2013). The economic consequences of China-Africa Relations: Debunking Myths in the Debate. Journal of Chinese Economic and Business Studies, 11(4), 261-277.

Badinger, H. \& Egger, P. (2016). Productivity Spill over across Countries and Industries: New evidence from OECD countries. Oxford Bulletin of Economics and Statistics, 78(4), 501-521.

Balchin, N., Hoekman, B. M., Martin, H., Mendez-Parra, M., Papadavid, P. \& Te Velde, D. W. (2016). Trade in Services and Economic Transformation.

Behera, S. R., Dua, P. \& Goldar, B. (2012). Foreign Direct Investment and Technology Spillover: Evidence Across Indian Manufacturing Industries. The Singapore Economic Review, 57(02), 1250011.

Bloom, N., Draca, M. \& Van Reenen, J. (2016). Trade Induced Technical Change? The Impact of Chinese Imports on Innovation, IT and Productivity. The Review of Economic Studies, 83(1), 87-117.

Coe, D. T. \& Helpman, E. (1995). International R\&D Spillover. European Economic Review, 39(5), 859-887. 
Diaw, D. \& Lessoua, A. (2013). Natural Resources Exports, Diversification and Economic Growth of CEMAC countries: On the Impact of Trade with China. African Development Review, 25(2), 189-202.

Duggan, V., Rahardja, S. \& Varela, G. (2013). Service Sector Reform and Manufacturing Productivity: Evidence from Indonesia.

Elu, J. U. \& Price, G. N. (2010). Does China Transfer Productivity Enhancing Technology to Sub-Saharan Africa? Evidence from Manufacturing Firms. African Development Review, 22(s1), 587-598.

Eschenbach, F. \& Hoekman, B. (2006). Services Policies in Transition Economies: on the EU and WTO as Commitment Mechanisms. World Trade Review, 5(3), 415-443.

Feldman, M. P. \& Kogler, D. F. (2010). Stylized Facts in the Geography of Innovation. Handbook of the Economics of Innovation, 1, 381-410.

Fernandes, A. M. \& Paunov, C. (2012). Foreign Direct Investment in Services and Manufacturing Productivity: Evidence for Chile. Journal of Development Economics, 97(2), 305-321.

Francois, J. F. (1990). Trade in Producer Services and Returns due to Specialization under Monopolistic Competition. Canadian Journal of Economics, 109-124.

Goldberg, P. K., Khandelwal, A. K., Pavcnik, N. \& Topalova, P. (2010). Multiproduct Firms and Product Turnover in the Developing World: Evidence from India. The Review of Economics and Statistics, 92(4), 1042-1049.

Griliches, Z. \& Lichtenberg, F. (1984). Interindustry Technology Flows and Productivity Growth: A Reexamination. The Review of Economics and Statistics, 324-329.

Grossman, G. M. \& Helpman, E. (1991). Trade, Knowledge Spillover, and Growth. European Economic Review, 35(2-3), 517-526.

Guellec, D. \& Van Pottelsberghe de la Potterie, B. (2004). From R\&D to Productivity Growth: Do the Institutional Settings and the Source of Funds of R\&D matter? Oxford Bulletin of Economics and Statistics, 66(3), 353-378.

Guerrieri, P. \& Meliciani, V. (2005). Technology and International Competitiveness: The interdependence between Manufacturing and Producer Services. Structural Change and Economic Dynamics, 16(4), 489-502.

Hall, B. H. \& Rosenberg, N. (2010). Handbook of the Economics of Innovation, Elsevier.

Industrial Development Cooperation. (2009). Trends in South African Manufacturing Production, Employment and Trade, Department of Research and Information, Fourth Quarter.

Kasahara, H. \& Rodrigue, J. (2008). Does the use of Imported Intermediates Increase Productivity? Plant-level evidence. Journal of Development Economics, 87(1), 106-118.

Keller, W. (2002). Trade and the Transmission of Technology. Journal of Economic growth, 7(1), 5-24.

Lee, G. (2006). The Effectiveness of International Knowledge Spillover Channels. European Economic Review, 50(8), 2075-2088.

Levine, R. (1997). Financial Development and Economic Growth: Views and Agenda. Journal of Economic Literature, 35(2), 688-726.

Lichtenberg, F. R. \& De La Potterie, B. V. P. (1998). International R\&D Spill over: a comment. European Economic Review, 42(8), 1483-1491.

Mattoo, A., Rathindran, R. \& Subramanian, A. (2006). Measuring Services Trade Liberalization and its Impact on Economic Growth: An illustration. Journal of Economic Integration, 64-98.

Medda, G. \& Piga, C. A. (2014). Technological Spillover and Productivity in Italian Manufacturing Firms. Journal of productivity analysis, 41(3), 419-434.

Mehta, S. (2013). Technology Spillover and Productivity: Analysis of the Indian Manufacturing Sector. Innovation and Development, 3, 55-69.

Melitz, M. J. (2003). The Impact of Trade on Intra-Industry Reallocations and Aggregate Industry Productivity. Econometrica, 71(6), 1695-1725.

Mun, S. B. \& Nadiri, M. I. (2002). Information Technology Externalities: Empirical Evidence from 42 US Industries (No. w9272). National Bureau of Economic Research.

Narayan, P. (2004). Reformulating Critical Values for the Bounds F-statistics Approach to Cointegration: An Application to the Tourism Demand Model for Fiji (Vol. 2). Australia: Monash University.

Nishioka, S. (2013). R\&D, Trade in Intermediate Inputs, and the Comparative Advantage of Advanced Countries. Journal of the Japanese and International Economies, 30, 96-110.

OECD. (2010). Measuring Innovation: A New Perspective. 
Pesaran, M. H. \& Smith, R. P. (1998). Structural analysis of co integrating VARS. Journal of Economic Surveys, 12(5), 471-505.

Pesaran, M. H., Shin, Y. \& Smith, R. J. (2001). Bounds Testing Approaches to the Analysis of Level Relationships. Journal of Applied Econometrics, 16(3), 289-326.

Piermartini, R. \& Rubínová, S. (2014). Knowledge Spill Over Through International Supply Chains (No. ERSD2014-11). WTO Staff Working Paper.

Potterie, B. V. P. D. L. \& Lichtenberg, F. (2001). Does Foreign Direct Investment Transfer Technology Across Borders? Review of Economics and Statistics, 83(3), 490-497.

Pradeep, V., Bhattacharya, M. \& Chen, J. R. (2017). Spillover Effects of Research and Development, Exports and Foreign Investment on Productivity: Empirical Evidence from Indian Manufacturing. Journal of South Asian Development, 12(1), 18-41.

Raouf Abdel Fattah, E. (2015). Total Factor Productivity and Technology Spillover in Egypt. Middle East Development Journal, 7(2), 149-159.

Renard, M. F. (2011). China's Trade and FDI in Africa. China and Africa: An emerging partnership for development, 25.

Romer, P. M. (1989). Increasing Returns and New Developments in the Theory of Growth (No. w3098). National Bureau of Economic Research.

Roquia Fane Madouka Koumou, Wang Manyi. (2016). Effects of Chinese Foreign Direct Investment in Africa. Journal of Finance and Accounting, 4(3), 131-139.

Schmookler, J. (1966). Invention and Economic Growth, Cambridge, MA; Harvard University Press.

Stock, J. H. \& Watson, M. W. (1993). A Simple Estimator of Cointegrating Vectors in Higher Order Integrated Systems. Econometrica: Journal of the Econometric Society, 783-820.

Park, J. Y. (1992). Canonical Cointegrating Regressions. Econometrica: Journal of the Econometric Society, 119-143.

Phillips, P. C. \& Hansen, B. E. (1990). Statistical Inference in Instrumental Variables Regression with I (1) Processes. The Review of Economic Studies, 57(1), 99-125.

Terleckyj, H. (1974). Effects of R\&D on the Productivity Growth of Industries: An Exploratory National Planning Association, Washington, D.C. 